\title{
A Study of Vegetation Geomorphology Relationship along the sections of Balasore and Kanthi Coastal Plains, India
}

\author{
Anurupa Paul ${ }^{1 *}$, Asim Debnath ${ }^{1}$, Joydeb Sardar ${ }^{2}$ and Jatisankar Bandyopadhyay ${ }^{1 \& 2}$
}

Abstract: Coastal geomorphology deals with the various landforms and different processes involved in the development of coast. In the alluvium coast, biology plays a significant role as a coastal process. The present study aims at the role of vegetation in the geomorphic system, with the main consideration of flora. The study has been conducted in an alluvium coast along the Bay of Bengal adjacent to the sections of Balasore and Kanthi coastal plain. The geomorphological map and Normalized Difference Vegetation Index (NDVI) have been generated with the help of Landsat 5 TM, Landsat 8 OLI \& SOI Toposheet with the help of Arc GIS \& Erdas Imagine software. The ground truthing of relationships between geomorphological units \& vegetation types are established with the help of GPS survey and counting of species type. The selected nine environmental transects of Balasore and Kanthi coastal plains i.e. Dagara, Kankadapal, Talsari, Udaipur, Digha, Shankarpur, Tajpur, Mandarmani \& Junput have been considered for assessing the role of vegetation in sediment accretion and sediment surface stability. The study shows that the surface stability is achieved with dense vegetation covers and their types in Mangrove Swamp, Salt marsh and sand dunes whereas; the erosional area of geomorphic units has less vegetation cover and insignificant species type. The perfect relationship are found in the shore transect of Balasore-Kanthi coastal interface area (New Digha to Bichitrapur). Finally, it is also observed that the above area is less disturbed by human activities in compare to others.

Keywords: Coastal Geomorphology, Alluvium Coast, Normalized Difference Vegetation Index (NDVI), Sediment Accretion \& Sediment Stability

\footnotetext{
Manuscript revised on March 1, 2021 and published on March 10, 2021

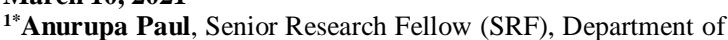
Remote Sensing \& GIS, Vidyasagar University, Midnapore721102, W.B, India,

1*Corresponding Email Id: anurupapaul2017@gmail.com

${ }^{1}$ Asim Debnath, M.Sc Student, Department of Remote Sensing \& GIS, Vidyasagar University, Midnapore-721102, W.B, India, 2Joydeb Sardar Research Scholar, Centre for Environmental Studies, Vidyasagar University, Midnapore-721102, W.B, India, 1\&2Jatisankar Bandyopadhyay, Assistant Professor, Department of Remote Sensing \& GIS, Vidyasagar University, Midnapore-721102, W.B, India and Deputy Director, Centre for Environmental Studies, Vidyasagar University, Midnapore721102, W.B, India,
}

\section{INTRODUCTION}

The Coastal morphology deals with the understanding of the landforms structure produced due to the erosional and depositional activities of the coast. The coastal morphology is a broad concept to discuss the relationship between the formation of erosional and depositional features. The predicted sea-level rise may produce the impacts on the coastal ecosystem as well as on the coastal inhabitations made by the people at the sea shore $[15,16]$. There are several methods for the estimations of coastal vulnerabilities to assess the impacts of different physical and environmental hazards. The morphological variations at the geographical space subjected to process variables and concentration of energy made the alluvium coast as dynamic landform with events of erosion, deposition \& transportation [4,6,7] The morphological structures are formed due to the high interaction of wave, tide, wind, current and grain sizes. The change of the morphology due to the processes led to the formation of numerous features. The present study area is highly susceptible to sea level rise and climate change impacts. Effective coastal zone management is needed to increase the resilience capacity of such coast for reduction of hazards on the infrastructural development and human settlement [3]. The coastal zone is a very complex environment, where the salt water meets the fresh water.

The terrestrial part of the coastal zone with its freshwater influx and sediment source as well as groundwater resources influences the marine environment along the coastal fringes and the marine area with its saltwater, storms, tides, currents \& storm surges influence the landward part of the same coast [6]. The coastal zone represents varied and highly productive ecosystems such as mangroves, sea grasses and sand dunes.

Today's coastal habitats of the alluvium shore line are highly converted by local people for urbanization, dense settlements \& infrastructure developments, which is other ways are responsible for the loss of coastal wetlands, unpredictable siltation and environmental degradation [18,19,21] (Fig.1). The future expansion in many undeveloped maritime countries will also be concentrated on coastal areas. Any human activities may cause dramatic change in the ecosystem functions of the 


\section{Available online at www.ijrat.org}

coastal habitats. Coastal development contributes to habitat loss in many ways. In the previous decades, the frequency of high magnitude cyclones as well as moderates magnitude of cyclones is increased in the tropical coast [20].

Coastal features at the interface of land and sea (beaches, sand dunes, wetlands, barrier islands, reefs etc.) act as physical barriers against storm damage. Mangroves, sand dunes sea beaches \& salt marshes are traditionally acted as coastal buffer against the strong sea waves, erosion intensity and cyclone landfalls in the low lying alluvium coasts $[18,9]$. The loss of such buffers by the human activities in the coast is directly responsible for the impact of low magnitude and moderate magnitude cyclones. The coastal vulnerability is rapidly increased due to industrial development, urbanization, agricultural practices, destruction of forests, fossil fuel burning, development of the transport system, draining wetlands, the adoption of modern technology in farming and livestock rearing etc. $[2,11,13]$ Thus, studies on the genesis, evolution and process involved in the formation of the surface forms of the coast represent its dynamic system which must be considered for various management policies to be adopted by environmental managers along the coast. The relative exposures of coastal engineering structures to the waves, currents \& storms have weakened the secondary stability factors along the coast [1]. Coastal zones are naturally very dynamic and economically highly productive which have been adversely affected by the impact of extreme natural events like tsunami, cyclonic storm surge, severe erosion and increased sea surface temperature as a result of global climatic changes over the past century. The alternate sequences of the temperature changes of the earth are recorded since $\sim 1900$ to 1940 experienced warm temperatures and during 1940 to 1965-1970 experienced relatively cool temperature and finally after 1970 onwards, the earth experienced warm temperature $[8,22]$ Geomorphology, ecology and, society of the coast offer most significant aspects of modern environmental issues for the coastal studies in different disciplines. Most of the hazards are turned into disastrous activities due to the inability of the potentially vulnerable communities due to socioeconomic inequalities, their proximity to the hazardous event, high population density, the degree of awareness and understanding, and poor infrastructure [14]

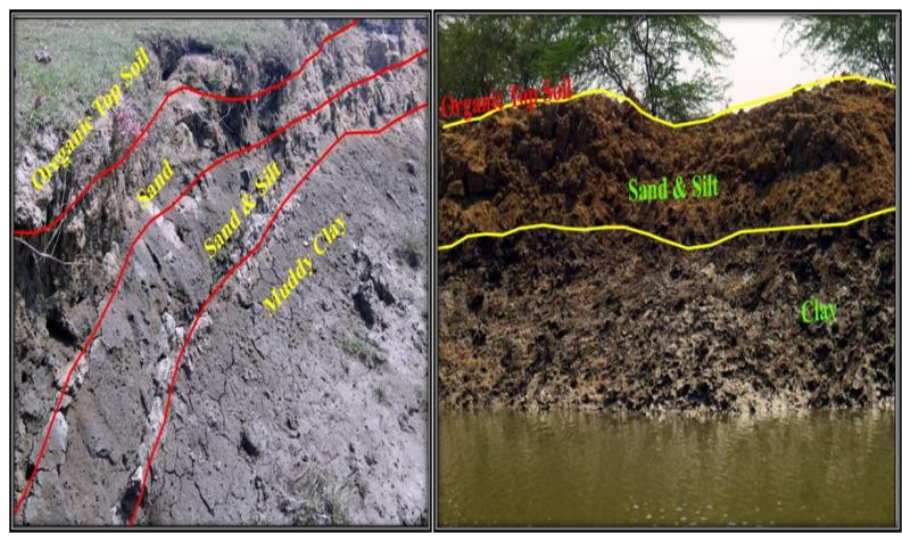

Fig.1: Soil Profile Zones along Bichitrapur

\section{COASTAL ZONE MANAGEMENT}

The progress made in remote sensing technologies and geographical information systems (GIS) represents an important contribution enabling us to face up to this challenge [5]. Coastal zone management, disaster management, environmental impacts analysis, and coastal zone regulation acts are the burning issues of the modern coasts. Coastal zones are geomorphologically dynamic, ecologically sensitive, biologically productive and rich in habitat diversity, and environmentally hazard prone under the events of tropical cyclone, tidal waves, climate change and sea level rise. Today, people are attracted by the available resource, space for various development activities, recreational facilities and various scopes for industrialization around the coasts. The low-lying coastal alluvial plains of the lower Ganga delta, Subarnarekha delta and Kanthi coastal tract are heavily populated at present. The combined impacts of increasing coastal populations at unprecedented rates, expected rise in sea level due to greenhouse induced warming and local subsidence rates will put significant stress on the coastal zones of the present study areas in the near future. The coastal zone stands as a collision course between the two ways of change - human related development changes and expected natural changes [17]. Today, the major threat to the coastal zone comes from the maritime disasters particularly resulting from estuarine pollution, marine pollution, over exploitation of natural resources at sea and high magnitude of cyclones. The damage is regularly caused by the southwest monsoon brace and the frequent cyclones are well known particularly around the low-lying coasts. 


\section{STUDY AREA}

The study area chosen in the present work is about 65.70 K.M, a long coastal stretch on the east coast of India, covering parts of Balasore and Kanthi coastal plains in Odisha and West Bengal States respectively, adjoining Bay of Bengal. The Western end of the study area is bounded by Dagara Sea Beach in Balasore (Odisha), while Junput Sea Beach in East Midnapore (West Bengal) forms the eastern boundary including two $\mathrm{CD}$ block of Baliapal, Bhograi of Balasore District of Odisha and four CD block Ramnagar-I, Ramnagar-II, Contai and Deshapran of East Midnapore District of West Bengal (Fig.2). Geographically, the study area is bounded by latitudes $21^{\circ} 28,56.71 " \mathrm{~N}-$ $21^{\circ} 47^{\prime} 44.80^{\prime \prime N}$ and longitudes $87^{\circ} 12^{\prime} 57.94 " \mathrm{E}$ $87^{\circ} 49^{\prime} 59.94$ "E. Subarnarekha is the Major river in this study area and there are so many inlet like Talsari Inlet, Digha Inlet, Jaldah Inlet and Pichaboni Inlet. There are 13 Study Points in this whole study area and they are Dagara Sea Beach $\left(21^{\circ} 33^{\prime} 11.89^{\prime \prime N}, 87^{\circ} 16^{\prime} 51.37^{\prime \prime E}\right)$, Kankadapal (21 $\left.33^{\prime} 4.91^{\prime \prime} \mathrm{N}, \quad 87^{\circ} 19^{\prime} 59.49^{\prime \prime} \mathrm{E}\right), \quad$ Chandrabali (21 $\left.34^{\circ} 21.36 " \mathrm{~N}, 87^{\circ} 22^{\prime} 30.71^{\prime \prime E}\right), \quad$ Bichitrapur (21 $\left.36^{\circ} 17.07 " \mathrm{~N}, \quad 87^{\circ} 24^{\prime} 54.54^{\prime \prime E}\right)$, Talsari Beach

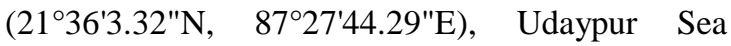

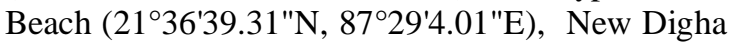
Sea Beach $\left(21^{\circ} 37^{\prime} 0.03^{\prime \prime N}, 87^{\circ} 30^{\prime} 10.61^{\prime \prime E}\right)$, Old Digha Sea Beach $\left(21^{\circ} 37^{\prime} 21.71^{\prime \prime N}, 87^{\circ} 31^{\prime} 33.27^{\prime \prime E}\right)$,

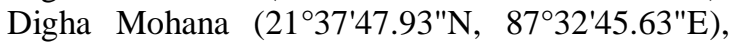
Shankarpur Beach (21 $38^{\prime} 15.49^{\prime \prime} \mathrm{N}$, 87³4'49.85"E), Tajpur Sea Beach (2138'39.80"N, 87³6'43.39"E), Mandarmani Beach (21 $\left.38^{\circ} 52.66^{\prime \prime N}, 87^{\circ} 38^{\prime} 40.37^{\prime \prime E}\right)$, Junput Sea Beach (21 $\left.42^{\circ} 46.41^{\prime \prime N}, 87^{\circ} 49^{\prime} 15.05^{\prime \prime} \mathrm{E}\right)$.

\section{MATERIALS \& METHODS}

In order for carrying out present study, a detailed plan of field observation had been prepared for the identification of species (Table.1). The methodology used in the present study is estimated using the relationship between geomorphic features and vegetation species in the coastal morphology. The coastal geomorphological map is generated from the Landsat 8 (OLI) image of 2017 \& Landsat 5 TM, Toposheet and Google by overlaying processes then vectorization of geomorphological classes has been done with the help of GPS Survey to identified geomorphological units by using Arc GIS 10.1 Software. Geomorphological features and Vegetation are identified in the ground truth verification with the help of random way in GPS Survey and also analysis in the Balasore to Kanthi coastal region to demarcate in the statistical frequency graph in the based on geomorphic units and the no of vegetation species (Fig.3).

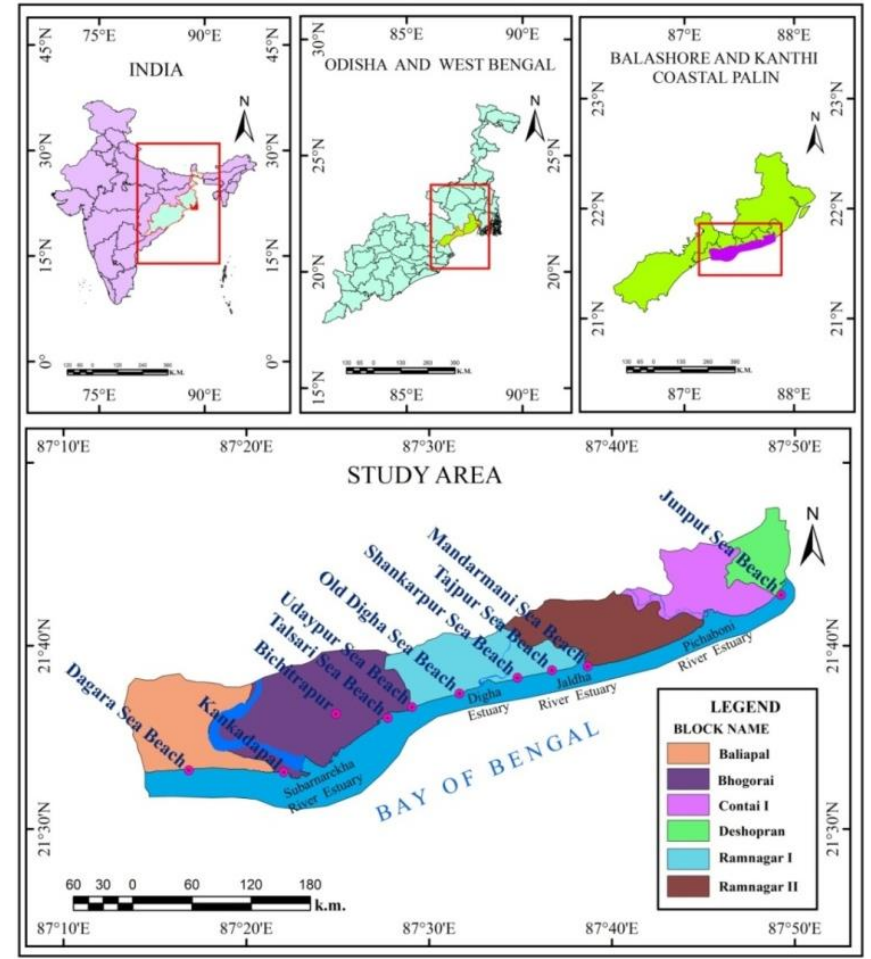

Fig.2: Location map of the study area

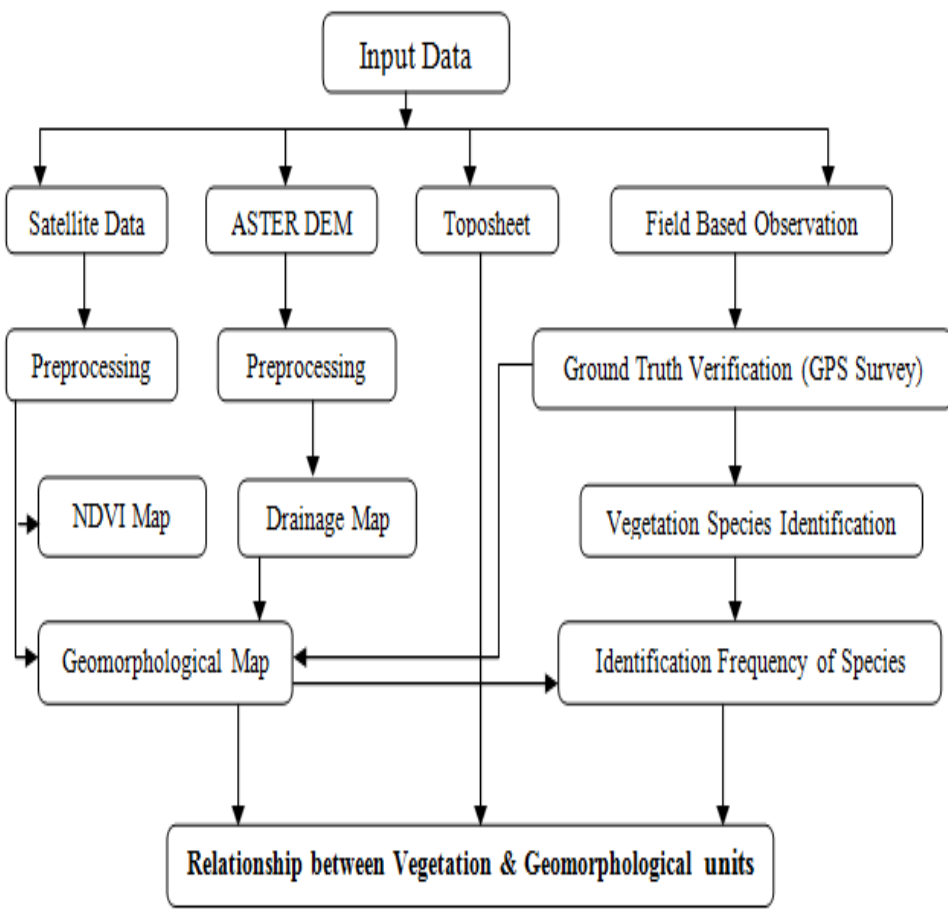

Fig.3: Conceptual methodological frame work of the research 


\section{Available online at www.ijrat.org}

TABLE.1: DETAILS OF THE DATA USED IN THE WORK

\begin{tabular}{|c|c|c|c|c|c|}
\hline $\begin{array}{c}\text { Sl. } \\
\text { No. }\end{array}$ & Data & $\begin{array}{c}\text { Date of } \\
\text { data } \\
\text { acquire }\end{array}$ & Source & $\begin{array}{l}\text { No of } \\
\text { Bands }\end{array}$ & $\begin{array}{c}\text { Resoluti } \\
\text { on }\end{array}$ \\
\hline 1 & $\begin{array}{l}\text { Land } \\
\text { Sat } 8 \\
\text { OLI/ } \\
\text { TIRS }\end{array}$ & $\begin{array}{c}15^{\text {th }} \\
\text { January } \\
2017\end{array}$ & $\begin{array}{c}\text { http://glovis } \\
\text {.usgs.gov/ }\end{array}$ & 11 & 30 \\
\hline 2 & $\begin{array}{c}\text { Land } \\
\text { sat } 5 \\
\text { TM }\end{array}$ & $\begin{array}{c}5^{\text {th }} \\
\text { January } \\
1990\end{array}$ & $\begin{array}{c}\text { http://glovis } \\
\text {.usgs.gov/ }\end{array}$ & 7 & 30 \\
\hline 3 & $\begin{array}{c}\text { AST } \\
\text { ER } \\
\text { Glob } \\
\text { al } \\
\text { DEM }\end{array}$ & $\begin{array}{c}17 \text { th } \\
\text { October } \\
2011\end{array}$ & $\begin{array}{c}\text { http://glovis } \\
\text {.usgs.gov/ }\end{array}$ & & 30 \\
\hline 4 & $\begin{array}{l}\text { Topo } \\
\text { sheet }\end{array}$ & 1972 & $\begin{array}{l}\text { Survey Of } \\
\text { India }\end{array}$ & & \\
\hline 5 & $\begin{array}{c}\text { Goog } \\
\text { le } \\
\text { Earth }\end{array}$ & 2018 & $\begin{array}{c}\text { Developed } \\
\text { by } \\
\text { keyhole,inc } \\
\text { a mountain } \\
\text { view based } \\
\text { company } \\
\text { founded in } \\
2001\end{array}$ & & \\
\hline
\end{tabular}

\section{RESULTS \& DISCUSSION}

The Drainage map helps us to identify the drainage features and its evaluation. The study area is showing concentration of dendritic pattern (Fig.4). From the south-western part to north-eastern part Digha river mouth lies under Digha coast, Jaldah river mouth lies between Shankarpur and Mandarmani coast. Pichaboni river mouth lies between Mandarmani and Junput coast but the major river estuary in the study area is Subarnarekha. This estuaries and river mouths mixes in the ocean of Bay of Bengal. These all rivers are mainly tidal rivers.

Normalized Difference Vegetation Index (NDVI) is a numerical indicator that uses the visible and near infrared bands of the Electromagnetic spectrum, and is adopted to analyse remote sensing measurements and assess whether the target being observed contains live green vegetation or not (Fig.5).

$$
\mathrm{NDVI}=\left(\mathrm{DN}_{\mathrm{NIR}}-\mathrm{DN}_{\mathrm{R}}\right) /\left(\mathrm{DN}_{\mathrm{NIR}}+\mathrm{DN}_{\mathrm{R}}\right)
$$

Geomorphology is the scientific study of the origin and evolution of topographic and bathymetric features created by physical, chemical or biological process. The study area is showing concentration of dendritic pattern. From the south-western part to north-eastern part Digha river mouth lies under Digha coast, Jaldah river mouth lies between Shankarpur and Mandarmani coast. Pichaboni river

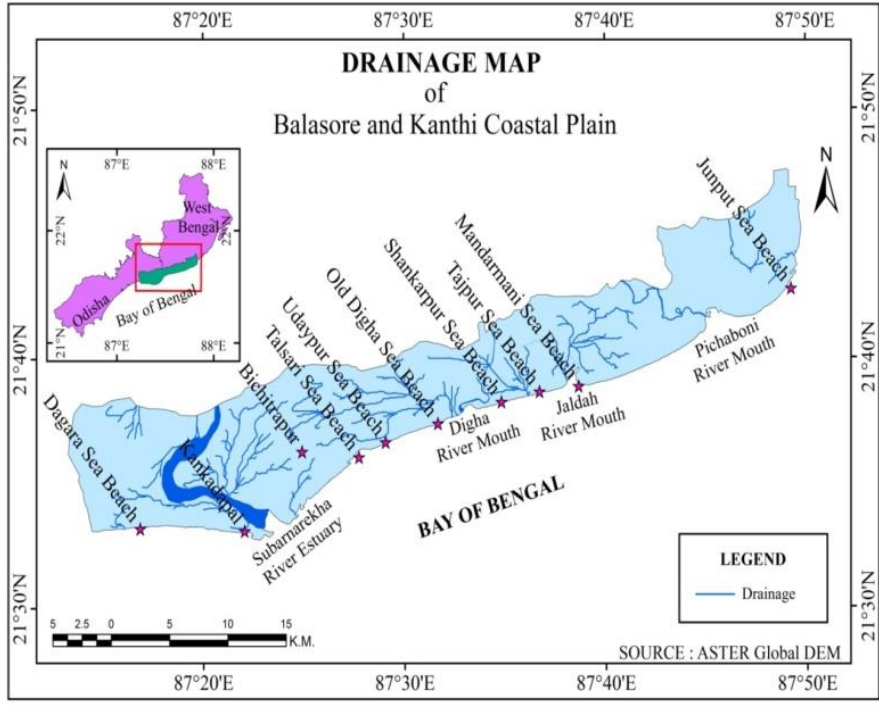

Fig.4: Drainage map of Balasore and Kanthi costal tract

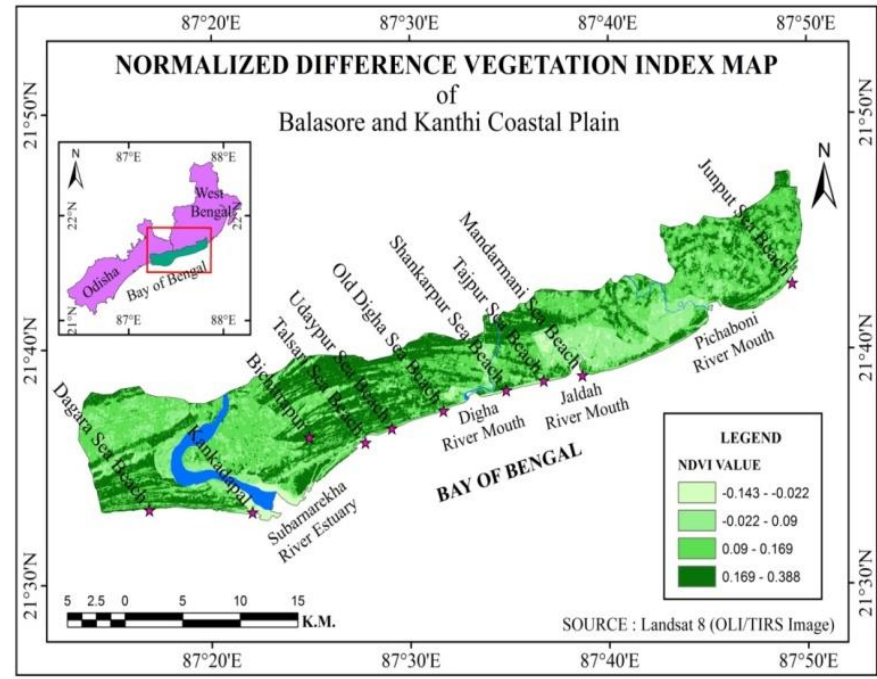

Fig.5: Normalized Difference Vegetation Index (NDVI) of Balasore and Kanthi coastal plain

mouth lies between Mandarmani and Junput coast but the major river estuary in the study area is Subarnarekha (Fig.6). This estuaries and river mouths mixes in the ocean of Bay of Bengal. These all rivers are mainly tidal rivers. In this study area, many geomorphological features are observed, which are given below: Spit, Sand Bars, River, Salt Marsh, Meander Bars, Vegetation, River Mouth, Tidal Creek, Mangrove Swamp, Older Dune Ridge, Abandoned River Channel, Paleo Beach Ridge, Younger Sand Dune, Modern Shoreline Beach, Younger Low-lying Coastal Plain, Paleo Beach Plain. 


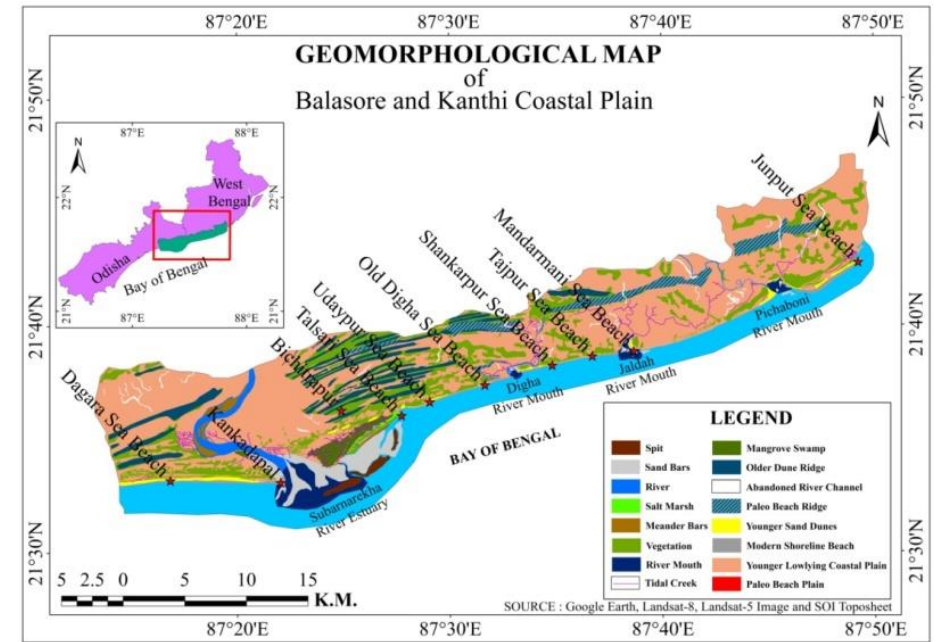

Fig.6: Geomorphological map showing the geomorphic zones of Balasore and Kanthi coastal plains

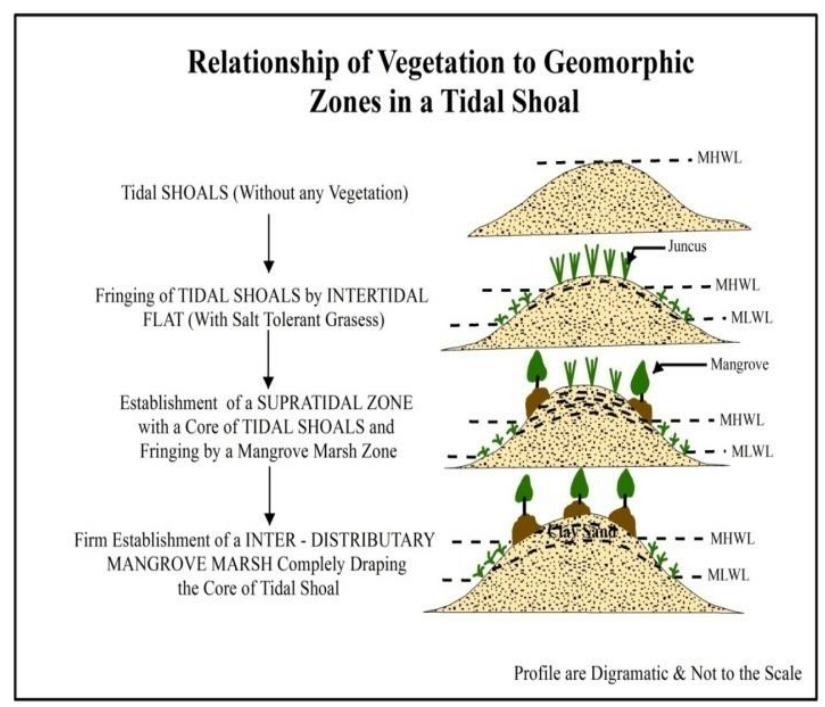

Fig.7: Relationship of Vegetation in Geomorphic zone in tidal shoal

\section{RELATIONSHIP BETWEEN VEGETATION AND GEOMORPHIC UNITS}

The colonization of vegetation in different geomorphic units of sedimentary landforms produces surface stability and increase the rate of sediment accretion. However, the sand dunes and vegetated tidal flats of the coastal zones are getting affected seriously by the formation of blow out spots on the sand dunes and increased rate of sheet erosion from the exposed tidal mud banks after the alarming rate of vegetation removal process by human induced activities in the coastal zone (i.e. land use conservation). Gradually, the surface stability of shoals and bars is achieved with the siltation rate and colony development of halophytic vegetations, and as the colony development spreads over the surface with time the accumulation rate of sediments increase the surface elevation and horizontal expansion of island platforms in the alluvium coast of the region with rapid supply of sediments in the monsoon phases by River Subarnarekha and River Hooghly [12]. The presence study also highlights the significance of vegetation colony development and frequency of species types with various geomorphic surfaces to establish the positive relationship between geomorphology and vegetation covers. The significance of vegetation colony development \& their existence should be carefully considered, in term of the sensitivity of sedimentary landforms to the biological process in the coast (Fig.7 \& 9).

\section{THE OPEN COAST BACK BARRIER TIDAL FLAT OF SUBARNAPUR - TALSARI AREAS (ORISSA COAST)}

Salt marshes and Mangroves coexist in a Narrow tidal Basin of Subarnarekha Delta under lagoonal setting and estuarine setting of the tropical coastal zone protected by a barrier spit extended along the shoreline of the Bay of Bengal. The enclosed coast line of the delta area is significant site for a net accumulation of sediments (tidal, marine and estuarine). Indeed the water and sediment regime are the two prime factors in marsh establishments, growth and differentiation. Such rooted plans of terrestrial origin cannot grow systematically unless the sediment accretionary surface is stable enough permit the rooting and growth habits of vegetations. The linear tidal basin is extended from the mouth of the Subarnarekha River to the east-north-east direction with $7 \mathrm{kms}$ in length and $0.5 \mathrm{~km}$. to 1.80 kms. In width, and sharply fed by Talsari Subarnapur tidal inlets across the barrier sand spit. A large colony of mangroves or halophytic woodland vegetations is restricted on the banks of Subarnapur tidal channel on the western part of tidal basin close to the river mouth environment of Subarnarekha (Table.2; Fig.8). 


\section{Available online at www.ijrat.org}

TABLE.2: NATURAL PHYSIOGRAPHIC SETTING OF BALASORE \& KANTHI COASTAL PLAINS

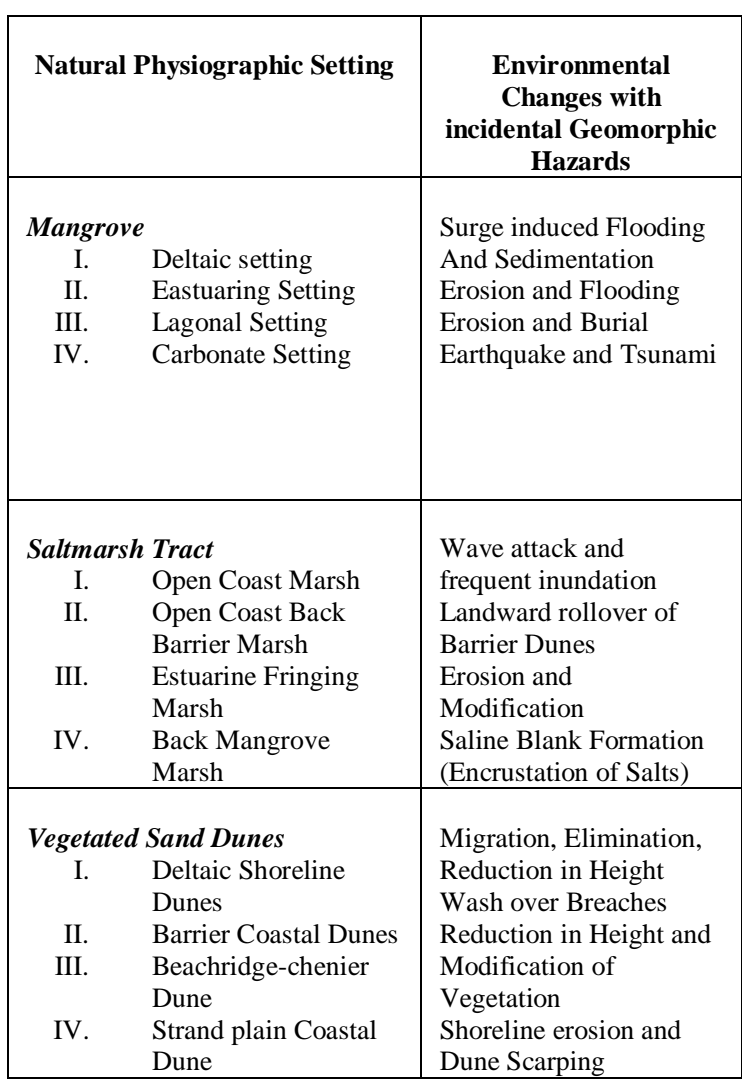

\section{SALTMARSH VEGETATION OF DIGHA MOHONA}

Bothe above - ground and underground conditions are very significant to the saltmarsh ecosystem. Above - ground waters come from the tidal flooding and local rainfall and the underground water relations of saltmarsh area are influenced by the above - ground ones and by drainage and seepage conditions. Thus the physical properties like tides, their period, amplitude and the subtract character of the saltmarsh have an influence on the zonation pattern of vegetation have started from the bare mud of the creek banks to the higher surface of saltmarsh. The shelving mud banks and the shallow mud flats are predominantly occupied by Porteresia coarctata (Dhanighas). This type of vegetation prefers the swampy floor and newer mud accreted surface for adjustment to the dynamic environment of saltmarsh. The sloping flat above this zone of vegetation with less frequent inundation, is mostly colonized by the species of Aeluropus lagopoides (Nona Durba). Finally, the higher marsh surface is densely colonized by
Salicirnia brachiata (Brahmmi sak) and Suaeda maritime (Giria sak) species. Salt concentration is also comparatively high in this surface than other areas of the saltmarsh due to the higher rate of exposure and evaporation (Table.3)

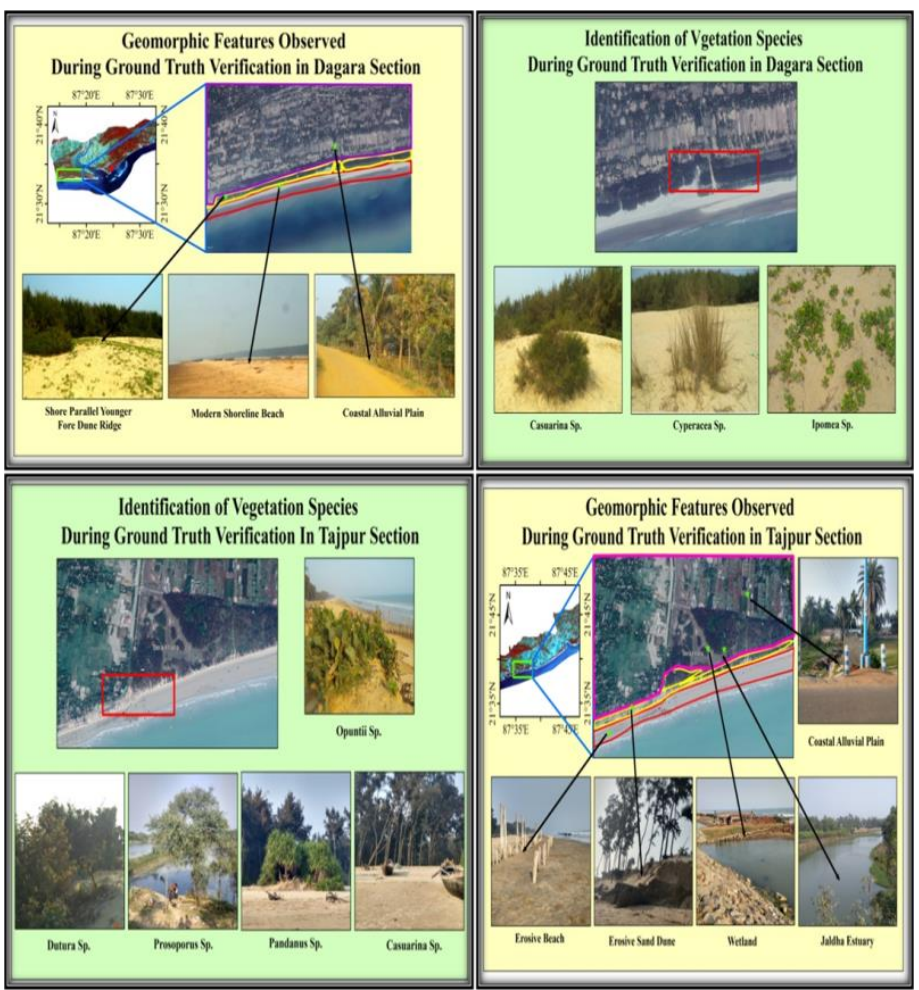

Fig.8: Vegetation Geomorphology Relationship along the sections of Dagara \& Tajpur Section

These are the three distinctively zones of saltmarsh vegetations in the saline wetland of Digha coast. Except these, some other vegetation is also frequently distributed in the swampy flats. Among them Suaeda nudiflora (Sada Giria sak), Avicenmia officinalis (Sada Bain), Acanthus ilicifolious (Harkach kanta) etc (Fig.9) are remarkable. Recently scattered distribution of Sesuvium portulacastrum (Gadabani sak) is also to be found in the sandy surface of creek banks and around salt - encrusted surface of the saltmarsh. Thus, with the density of the saltmarsh vegetations the sediment accretion process slowly and gradually by which maturation process of the saltmarsh topography is promoted. The mud flats and creek bank sand flats also provide attachment surface for a small number of algal communities in the saltmarsh habitat. 
TABLE.3: DIFFERENT VEGETATION SPECIES IDENTIFICATION IN DIFFERENT GEOMORPHIC UNIT

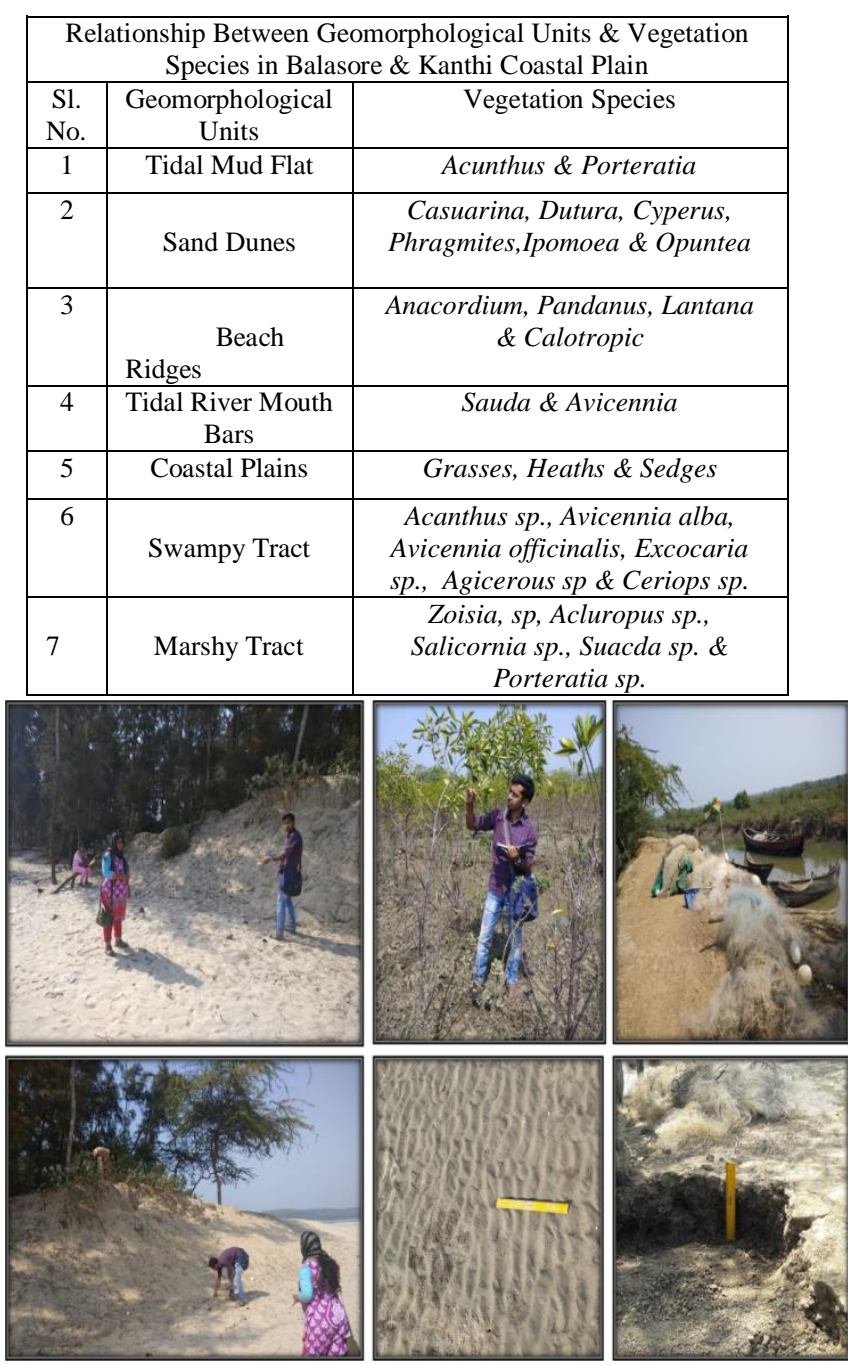

Fig.10: Field study showing different types of morphological units and vegetation species in the coastal tract of Balasore \& Kanthi Coastal Plain

\section{CONCLUSION}

Sediment stockpiling takes place in the tidal mudflats with the baffling effects of salt marsh and mangrove vegetations in the period of tidal inundations as do sand dunes in the beach fringed areas with blocking effects of shoreline vegetations in the period of windblown sand movement in the sandy coast. The present study shows that the windblown depositional layers between two successive decomposed organic layers trapped in the past sedimentary sections are varying in thickness which exposed in the erosive section of dune cliffs at present all along the coastline. From measuring records it is proved that windblown
Relationship Between Geomorpholoical Units \& Vegetation Species of Balasore \& Kanthi Coastal Plain

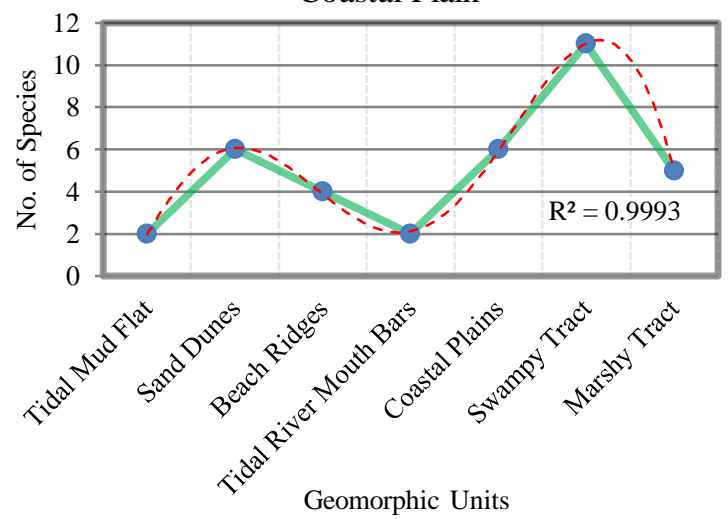

Fig.9: Relationship between geomorphological units \& vegetation species in the coastal tract of Balasore \& Kanthi

deposits might ranges from $8 \mathrm{~cm}$. to $12 \mathrm{~cm}$. per year in the coast preferably induced by vegetation obstructions and micro-topographic variations in the coastline (Fig.10). The sediment accretion rates may vary from saltmarsh areas, and mangrove dominated areas to sand dunes of active vegetation covers in the coast but sediment surface stability provided by them depend on less storminess of the sea, shoreline configuration and shelted areas of the coast. Buffering capacity of vegetation also differ from plant to plant in areas of more sediment supply and less sediment supply. Thus, fresh silts are stabilized in many cases by colonization of Avicennia sp. and Rhizophora sp. at the shorefront positions of the Kanthi coastal plain. Porteretia coarctata and Oryza coarctata at lower saltmarsh and surface stability is achieved by colonization of Sesuvium portulacustrum and Ipomea $s p$. at the fore dunes of the sandy coast. However, in the hot and dry summer phase when most of the dune herbs and grasses become dried out only Spinifiex litorious and Cyperus exultantus survive with strong buffering capacity against windblown sand deposition, high surface temperature, low field moisture and strong wind velocity $(35 \mathrm{~km} / \mathrm{hr}$. to 50 $\mathrm{km} / \mathrm{hr}$.) at the open shore environment of West Bengal and Orissa coasts.

\section{ACKNOWLEDGEMENTS}

We want to extend our thanks to Dr. Ashis Kumar Paul, Department of Geography, Vidyasagar University and Adv. Surya Anil Umbarje for their guidance and assistance in the field works. 


\section{Available online at www.ijrat.org}

\section{REFERENCES}

[1] Ahrens, John P. Characteristics of Reef Breakwaters. COASTAL ENGINEERING RESEARCH CENTER VICKSBURG MS, 1987.

[2] Anfuso, Giorgio, and José Ángel Martínez Del Pozo. "Assessment of coastal vulnerability through the use of GIS tools in South Sicily (Italy)." Environmental Management 43, no. 3 (2009): 533-545.

[3] Abuodha, Pamela AO, and Colin D. Woodroffe. "Assessing vulnerability to sea-level rise using a coastal sensitivity index: a case study from southeast Australia." Journal of coastal conservation 14, no. 3 (2010): 189-205.

[4] Bird, Eric Charles Frederick, and E. C. F. Bird. Submerging coasts: the effects of a rising sea level on coastal environments. Chichester: Wiley, 1993.

[5] Boateng, Isaac. "GIS assessment of coastal vulnerability to climate change and coastal adaption planning in Vietnam." Journal of Coastal Conservation 16, no. 1 (2012): 2536.

[6] Carter, R. W. G., and J. D. Orford. "Conceptual model of coarse clastic barrier formation from multiple sediment sources." Geographical Review (1988): 221-239

[7] Forbes, Donald L., George S. Parkes, Gavin K. Manson, and Lorne A. Ketch. "Storms and shoreline retreat in the southern Gulf of St. Lawrence." Marine Geology 210, no. 1-4 (2004): 169-204.

[8] Hansen, James, R. Ruedy, Mki Sato, Mki Imhoff, W. Lawrence, David Easterling, T. Peterson, and Thomas Karl. "A closer look at United States and global surface temperature change." Journal of Geophysical Research: Atmospheres 106, no. D20 (2001): 23947-23963.

[9] Jadidi, Amaneh, Mir Abolfazl Mostafavi, Yvan Bédard, Bernard Long, and Eve Grenier. "Using geospatial business intelligence paradigm to design a multidimensional conceptual model for efficient coastal erosion risk assessment." Journal of coastal conservation 17, no. 3 (2013): 527-543

[10] Lins-de-Barros, Flavia Moraes, and Dieter Muehe. "The smartline approach to coastal vulnerability and social risk assessment applied to a segment of the east coast of Rio de Janeiro State, Brazil." Journal of coastal conservation 17, no. 2 (2013): 211-223.

[11] Mujabar, P. Sheik, and N. Chandrasekar. "Coastal erosion hazard and vulnerability assessment for southern coastal Tamil Nadu of India by using remote sensing and GIS." Natural Hazards 69, no. 3 (2013): 1295-1314.

[12] Maiti, Sabyasachi. "Interpretation of coastal morphodynamics of Subarnarekha estuary using integrated cartographic and field techniques." Current Science (2013): 1709-1714.

[13] Mahapatra, Manik, Ratheesh Ramakrishnan, and A. S. Rajawat. "Coastal vulnerability assessment using analytical hierarchical process for South Gujarat coast, India." Natural Hazards 76, no. 1 (2015): 139-159.

[14] Mazumdar, Jublee, and Saikat Kumar Paul. "Socioeconomic and infrastructural vulnerability indices for cyclones in the eastern coastal states of India." Natural Hazards 82, no. 3 (2016): 1621-1643.

[15] Nicholls, Robert J., Poh Poh Wong, Virginia Burkett, Jorge Codignotto, John Hay, Roger McLean, Sachooda Ragoonaden et al. "Coastal systems and low-lying areas." (2007).

[16] Nicholls, Robert J., Poh Poh Wong, Virginia Burkett, Colin D. Woodroffe, and John Hay. "Climate change and coastal vulnerability assessment: scenarios for integrated assessment." Sustainability Science 3, no. 1 (2008): 89-102

Paul, Ashis Kr." Coastal sand dunes .In: Coastal Geomorphology \& Environment", 2002. acb publications Calcutta, pp.165-187.

[17] Paul. Anurupa Mangrove Swamp, Salt Marshes and Sand Dunes of Orissa and West Bengal in Coastal Environment and Dune Ecology, Phytography of Salt Marshes, Mangroves, and Sand Dunes Along The Coastal Belt of West Bengal, (2012): $32-48$.
[18] Paul, Ashis Kr. \& Paul Anurupa "Coastal Environment \& Dune Ecology. In: Phytography of Saltmarshes, Mangroves and Sand dunes along the coastal belt of West Bengal" (2013):. (Ed. Devmita Dinda) Mugberia Gangadhar Mahavidyalaya, ISBN93-80332-46-7 pp-22-69.

[19] Parthasarathy, Anitha, and Usha Natesan. "Coastal vulnerability assessment: a case study on erosion and coastal change along Tuticorin, Gulf of Mannar." Natural Hazards 75, no. 2 (2015): 1713-1729.

[20] Purkait, Barendra, Dipanjan Das Majumdar, and Ashis Kumar Paul. "Grain sorting on a coastal dune of Orissa, Bay of Bengal and a comparison with the desert dune of Rajasthan, India." International Research Journal of Earth Sciences 3, no. 8 (2015): 14-31

[21] Trenberth, Kevin E., Philip D. Jones, Peter Ambenje, Roxana Bojariu, David Easterling, A. Klein Tank, David Parker et al. "Observations. Surface and Atmospheric Climate Change. Chapter 3." (2007).

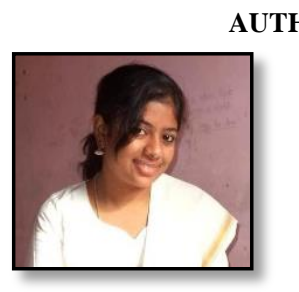

\section{UTHORS PROFILE}

Anurupa Paul, has completed her M.Sc in Geography from Savitribai Phule Pune University, Maharashtra and obtained her second M.Sc in Environmental Science from Vidyasagar University, West Bengal. She is doing her Ph.D. research from Department of Remote Sensing and GIS as a Senior Research Fellow (UGC-SVSGC-SRF). She was awarded as Young Scientist in 2013 from Savitribai Phule Pune University. She has published 12 articles in reputed international journals and national journals. She has presented her research work in Kuala Lumpur, Malaysia (38 $8^{\text {th }}$ ACRS Conference), 12 international conferences and 25 national conferences. She has also participated in 21 workshops and 70 webinars. She has received 5 best paper presentation awards in Seminars. Her area of interest in research is mainly focused on Coastal Geomorphology, Limestone Geomorphology, Environmental Geoscience, Earth Science and application of Remote Sensing \& GIS.

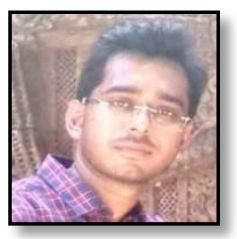

Asim Debnth, has completed his M.Sc in Remote Sensing \& GIS from Vidyasagar University, West Bengal. He is currently working as GIS Executive in Genesys International Corporation Ltd., Hyderabd, Telangana, India.

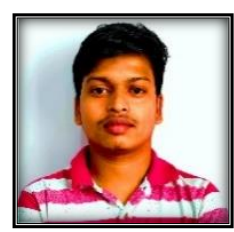

Joydeb Sardar is doing his Ph.Ds. research from Centre for Environmental Studies, Vidyasagar University, West Bengal. He has completed his M.Sc in Remote Sensing \& GIS from Vidyasagar University, West Bengal. $\mathrm{He}$ has participated in 8 workshops and 20 webinars. He has presented his research works in 2 International and 4 National conferences. He has published 4 research articles in International journals. His area of research includes Earth System Science, Environmental Studies, Tropical Geomorphology, Coastal Geomorphology and application of Remote Sensing and GIS.

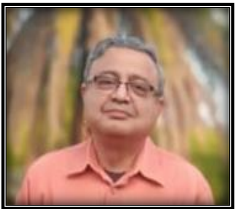

Dr. Jatisankar Bandyopadhyay, has been currently working as Head, Department of Remote Sensing \& GIS, and Deputy Director, Centre for Environmental Studies, Vidyasagar University, West Bengal. $\mathrm{He}$ has 
International Journal of Research in Advent Technology, Vol.9, No.2, February 2021

E-ISSN: 2321-9637

Available online at www.ijrat.org

completed his M.Sc in Applied Geology from University of Allahabad, M.Phil. \& Ph.D. from School of Environmental Sciences, Jawaharlal Nehru University, New Delhi. His broad area of research includes Geology, Earth Science, Disaster Management, Environmental Studies and application of Remote Sensing \& GIS. He has supervised 8 (awarded) and 10 (ongoing) Ph.D. Scholars, M.Phil. students and more than 150 M.Sc students for dissertation work. He has published more than 100 articles and book chapters in reputed international journals, national journals and edited book volumes. He has presented papers in more than 40 national and international conferences. $\mathrm{He}$ has participated in 34 workshops and 10 webinars. He has received 3 best paper awards. He has completed 5 projects and is engaged with 2 ongoing projects as Principal Investigator with SAC, Ahmedabad and INCOIS, Govt. of India. He is a reviewer of many international journals and member of INCOIS, INCA, ISRS and many other reputed organizations. He promotes a stimulating learning and development environment with his vast teaching and research experience of over 28 years, verbal communication, excellent administrative and leadership skills. 